\title{
PELATIHAN KULTIVASI SPIRULINA BAGI SISWA DAN SISWI SMA/SMK DI DAERAH SURABAYA, SIDOARJO DAN SEKITARNYA
}

\author{
Pungky Slamet WK ${ }^{1)}$, Tatang Sopandi ${ }^{2}$ \\ ${ }^{1,2}$ Program Studi Biologi, Fakultas Matematika dan Ilmu Penetahuan Alam, Universitas PGRI Adi Buana, \\ Jalan Ngagel Dadi IIIB/37 Wonokromo, Surabaya 60245, Jawa Timur, INDONESIA. \\ Email: ${ }^{2}$ tatang_sopandi@yahoo.com
}

\begin{abstract}
Abstrak
Produk mikroalga mengalami peningkatan dari waktu ke waktu karena berpotensi menghasilkan beragam bahan kimia dan senyawa aktif biologis seperti vitamin, pigmen karotenoid, protein, lipid dan polisakarida. Selain itu produk mikroalga ini diminati karena memberikan nilai manfaat ekonomi terkait dengan eksploitasi kultur mikroalga secara massal. Namun didalam pelaksanaanya masih banyak ditemukan kendala untuk memproduksi mikroalga ini karena ada beberapa cara budidaya untuk menghasilkan produk mikroalaga yang optimal. Untuk memecahkan masalah ini diperlukan pelatihan dan pendampingan. Tujuan kegiatan pelatihan untuk memberikan informasi dan pengetahuan tentang cara kultivasi spirulina dengan harapan merangsang peserta pelatihan untuk menekuni usaha berbasis spirulina sehingga dapat menggerakkan ekonomi berbasis spirulina. Hasil pelatihan kultivasi spirulina ini bagi peserta didik diperoleh informasi baru mengenai potensi dan manfaat ekonomi dari budidaya spirulina sebagai sumber pakan, sumber pangan dan energi alternatif yang terjangkau dengan teknologi sederhana yang dapat digunakan untuk mewujudkan kemandirian.
\end{abstract}

Kata kunci : Pelatihan, kultivasi spirulina, sumber pakan dan energi alternative

\begin{abstract}
Microalgae products have increased from time to time because of the potential to produce a variety of chemicals and biologically active compounds such as vitamins, carotenoid pigments, proteins, lipids/, polysaccharides. Also besides, this microalgae product is in demand because it provides a value of economic benefits associated with the mass exploitation of microalgae culture. But in its implementation, there are still many obstacles to producing this microalga because there are several ways of cultivation to produce optimal micro-product products. To solve this problem training and assistance are needed. The purpose of the training activities is to provide information and knowledge on how to cultivate spirulina in the hope of stimulating the trainees to pursue a spirulina-based business so that they can drive a spirulina-based economy. The results of this Spirulina cultivation training for students obtained new information about the potential and economic benefits of spirulina cultivation as an affordable source of food, food, and alternative energy with simple techniques that can be used to realize independence.
\end{abstract}

Keywords: Training, spirulina cultivation, alternative sources of food and energy

\section{PENDAHULUAN}

Kegiatan pengabdian masyarakat yang dilakukan Program Studi Biologi FMIPA UNIPA Surabaya saat ini adalah pelatihan kultivasi spirulina yang sangat berkaitan dengan minat para ilmuwan dan masyarakat untuk memanfaatkan proses bioteknologi mikroalga yang dari waktu ke waktu 
mengalami peningkatan, karena bioteknologi mikroalga ini berpotensi untuk menghasilkan beragam bahan kimia dan senyawa aktif biologis, seperti vitamin, pigmen karotenoid, protein, lipid dan polisakarida. Selain itu bioteknologi mikroalga diminati karena memberikan nilai manfaat ekonomi terkait dengan eksploitasi kultur mikroalga secara massal Agustina dan Herman (2016). Perhatian yang tinggi terhadap produksi biomassa mikroalga ini disebabkan karena kandungan proteinnya yang tinggi yaitu sekitar $60-70 \%$ dari berat kering biomassa Spirulina, kecernaan tinggi, dan kandungan seimbang antara beberapa asam amino esensial (Neto et al., 2014; Baweja et al., 2016). Biomassa Spirulina spp. dapat dijadikan contoh representatif dari produksi mikroalga.

Banyak spesies mikroalga yang telah digunakan untuk memproduksi pakan ternak, nutrisi pangan, kosmetik, dan komponen industri farmasi (Couteau, C. and L. Coiffard. 2016; Oktarina, E. 2017). Mikroalga juga telah digunakan dalam proses pengolahan air limbah, fiksasi $\mathrm{CO}_{2}$, dan pengurangan emisi gas rumah kaca. Selain itu teknologi mikroalga ini terbukti dapat menjadi sumber energi yang bersih dan terbarukan karena hasil yang diperoleh tinggi dan persyaratan spasial yang rendah, jika dibandingkan dengan tanaman yang hidup didaratan. Secara umum terdapat 2 metode kultifasi spirulina dalam skala besar yaitu melalui kultifasi kolam pacu (raceway ponds) dan fotobioreaktor (Janssen et al., 2003). Dari hasil penelitian yang telah dilakukan membuktikan bahwa kontrol terhadap parameter pertumbuhan pada metode fotobioreaktor lebih baik dibandingkan dengan kolam pacu, sehingga produktivitas biomassa yang dihasilkan lebih tinggi dan masalah kontaminasi dapat dikendalikan. Di sisi lain, kolam terbuka memiliki operasi dan konstruksi yang lebih mudah, meskipun masih ditemukan keterbatasan dalam pengendalian kondisi kultifasinya. Namun, pada kondisi yang ideal, kolam pacu merupakan sistem yang terbaik untuk produksi biomassa dalam skala besar (Ugwu et al., 2008).

Pelatihan kultivasi spirulina ini ditujukan pada siswa dan siswi SMA dan SMK di Surabaya, Sidoarjo dan sekitarnya guna menyebarluaskan pengetahuan bagi siswa tentang mikroalga spirulina serta memotivasi mereka untuk memanfatkan potensi spirulina ini menjadi suatu bentuk produk usaha baru yang dapat menghasilkan pendapatan dan meningkatkan kesejahteraan perekonomian bagi peserta didik dikemudian hari. Sedangkan manfaat kegiatan pelatihan bagi peserta didik diperoleh informasi mengenai potensi dan manfaat ekonomi dari budidaya spirulina sebagai sumber pakan, sumber pangan dan energi alternatif yang terjangkau dan teknologi sederhana yang dapat digunakan untuk mewujudkan kemandirian.

\section{METODE PELAKSANAAN}

Waktu pelaksanan tanggal 1-30 September 2019 dengan tempat pelaksanaan pelatihan Kegiatan Pengabdian Masyarakat (PKM) dosen Biologi tahun 2019 di Laboratorium Biologi Dasar Program Studi Biologi FMIPA UNIPA Surabaya. Peserta Pelatihan program PKM di Prodi Biologi FMIPA UNIPA ini berasal dari Siswa dan Siswi SMA dan SMK di Surabaya dan Sidoarjo, dihadiri oleh 42 siswa dan siswi. Materi pelatihan menjelaskan informasi dan pengetahuan tentang cara kultivasi spirulina dan budidayanya.

\section{HASIL DAN PEMBAHASAN}

Program Pengabdian pada Masyarakat (PPM) yang dilaksanakan di Program Studi Biologi FMIPA Universitas PGRI Adi Buana Surabaya ini dihadiri oleh 42 siswa/siswi yang berasal dari SMA/SMK di Surabaya dan Sidoarjo. Kegiatan pelatihan diawali dengan sambutan dari Bapak Wakil Dekan I FMIPA dan Ibu Kaprodi Biologi, kemudian sebelum kegiatan penyampaian materi dilakukan, siswa dan siswi peserta pelatihan diberi kegiatan mengisi pretest (tes awal) dan posttest (tes akhir setelah pelatihan) untuk mengetahui pengetahuan mengenai cara kultivasi spirulina dan budidayanya. 
Dibawah ini disajikan hasil pre dan post test seperti berikut:

Tabel 1. Pretest dan posttest pelatihan kultivasi spirulina

\begin{tabular}{|c|c|c|c|c|c|}
\hline \multirow[t]{2}{*}{ No. } & \multirow[t]{2}{*}{ Pertanyaan } & \multicolumn{2}{|c|}{ Pretest } & \multicolumn{2}{|c|}{ Postest } \\
\hline & & $\mathbf{Y a}$ & Tidak & Ya & Tidak \\
\hline 1 & $\begin{array}{l}\text { Apakah anda } \\
\text { pernah } \\
\text { mendengar } \\
\text { produk } \\
\text { mikroalga }\end{array}$ & & $\checkmark$ & & \\
\hline 2 & $\begin{array}{l}\text { Apakah anda } \\
\text { mengetahui } \\
\text { apa manfaat } \\
\text { produk } \\
\text { mikroalga }\end{array}$ & & $\checkmark$ & & \\
\hline 3 & $\begin{array}{l}\text { Apakah anda } \\
\text { mengetahui } \\
\text { proses } \\
\text { produksi } \\
\text { produk } \\
\text { mikroalga }\end{array}$ & & $\checkmark$ & & \\
\hline 4 & $\begin{array}{l}\text { Apakah anda } \\
\text { mengetahui } \\
\text { apa itu } \\
\text { spirulina }\end{array}$ & & & & \\
\hline 5 & $\begin{array}{l}\text { Apakah anda } \\
\text { mengetahui } \\
\text { tentang } \\
\text { budidaya } \\
\text { spirulina }\end{array}$ & & & & \\
\hline
\end{tabular}

Tabel 2. Kepuasan peserta pelatihan budidaya spirulina

\begin{tabular}{|c|c|c|c|c|c|}
\hline No. & Pertanyaan & SS & $\mathbf{S}$ & TS & STS \\
\hline 1 & $\begin{array}{l}\text { Saya merasa puas } \\
\text { dengan kegiatan } \\
\text { pelatihan spirulina }\end{array}$ & & & & \\
\hline 2 & $\begin{array}{l}\text { Kegiatan ini } \\
\text { sesuai dengan } \\
\text { harapan saya }\end{array}$ & & & & \\
\hline 3 & $\begin{array}{l}\text { Materi sangat } \\
\text { relevan dan } \\
\text { mudah difahami }\end{array}$ & & & & \\
\hline 4 & $\begin{array}{l}\text { Setiap pertanyaan } \\
\text { yang saya ajukan } \\
\text { ditindaklanjuti } \\
\text { dengan baik oleh } \\
\text { nara sumber yang } \\
\text { terlibat }\end{array}$ & & & & \\
\hline 5 & $\begin{array}{l}\text { Jika kegiatan ini } \\
\text { diselengarakan }\end{array}$ & & & & \\
\hline & kembali, & & & & \\
\hline
\end{tabular}

bersedia untuk

berpartisipasi

Keterangan: $\mathrm{SS}=$ Sangat setuju $\mathrm{S}=$ Setuju TS= Tidak setuju STS= Sangat tidak setuju

Selanjutnya pemateri menerangkan tentang kultivasi spirulina. Budidaya atau kultivasi mikroalga dalam skala besar dimulai pada awal tahun 1960-an di Jepang yang membudidayakan Chlorella, selanjutnya pada tahun 1970, budaya Spirulina di dilakukan di danau Texcoco di kota Mexico. Pada tahun 1977, Dai Nippon Ink and Chemicals Inc. membangun fasilitas produksi spirulina secara komersial di Thailand dan pada tahun 1980 terdapat 46 fasilitas skala besar di Asia yang memproduksi lebih dari $1000 \mathrm{~kg}$ mikroalga per bulan, terutama Chlorella dan pada tahun 1996 hampir 2.000 ton Chlorella dipasarkan di Jepang. Produksi Dunaliella salina sebagai sumber $\beta$-karoten merupakan mikroalga ketiga di antara produksi industri mikroalga yang dilakukan oleh Western Biotechnology Ltd. dan Betatene Ltd. di Australia pada tahun 1986.

Pemateri menjelaskan tentang 2 metode kultifasi spirulina dalam skala besar yaitu melalui budidaya kolam pacu (raceway ponds) dan fototobioreaktor. Kontrol terhadap parameter pertumbuhan pada metode fotobioreaktor terbukti lebih baik dibandingkan dengan kolam pacu sehingga produktivitas biomassa spirulina yang diperoleh lebih tinggi dan masalah kontaminasi dalam pelaksanaanya dapat dikendalikan. Di sisi lain, kolam terbuka juga memiliki operasi dan konstruksi yang lebih mudah, meskipun masih ditemukan keterbatasan dalam pengendalian kondisi budidayanya. Namun, pada kondisi budidaya yang ideal, kolam pacu merupakan sistem terbaik untuk produksi biomassa spirulina dalam skala besar. 


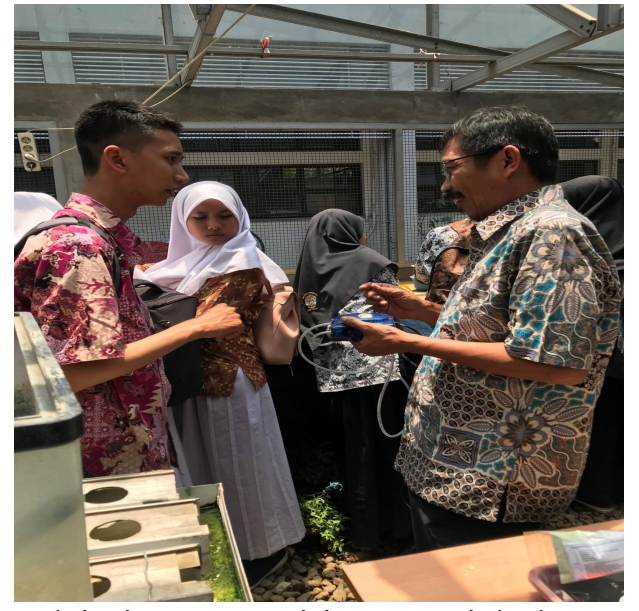

Selain itu pemateri juga menjelaskan tentang penyiapan kultifasi spirulina dalam fotobioreaktor dan di dalam kolam. Setelah itu, peserta pelatihan diajak oleh tim PKM ke Greenhouse untuk melihat hasil budidaya spirulina dan bagaimana panen spirulina dilakukan pada teknik fotobioreaktor. Selain itu peserta pelatihan juga dijelaskan mengenai teknik panen dengan filtrasi dan pasca panen spirulina.

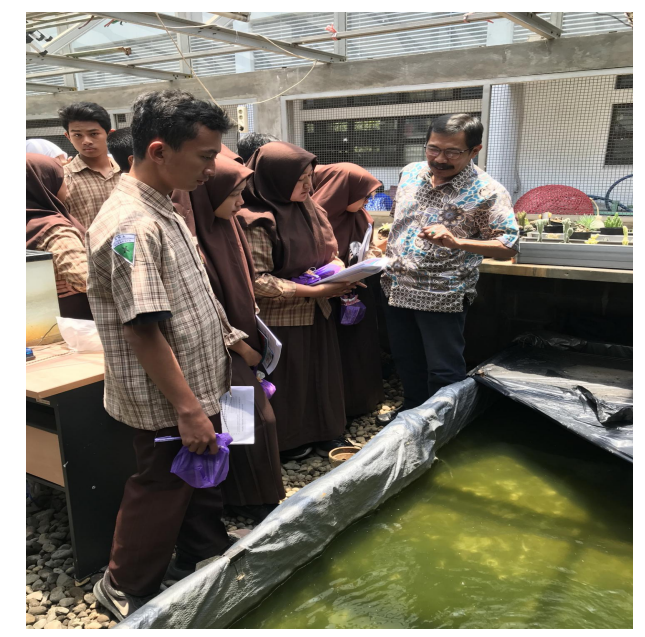

Gambar 1. Tim PKM menjelaskan pada peserta kultivasi spirulina

Hasil pretest dan posttest menunjukan para peserta pelatihan kultivasi sprirulina dalam pelaksanaan pelatihan, peserta selalu diberi kesempatan untuk melakukan praktik langsung dengan menggunakan bahan dan peralatan yang telah disiapkan oleh tim PKM dan pelaksanaan praktek kultivasi spirulina dilakukan setelah sesi ceramah dan diskusi selesai dilakukan oleh tim
PKM. Selanjutnya pada saat praktik kultivasi spirulina, para peserta pelatihan sudah menyiapkan bahan dan peralatan di greenhouse. Dalam pelaksanaannya para peserta pelatihan didampingi oleh tim PKM.

Berdasar hasil pengamatan selama kegiatan praktik kultivasi spirulina ini, semua peserta pelatihan mampu untuk melakukan kegiatan praktik sesuai dengan petunjuk yang telah disiapkan oleh tim PKM. Namun ada beberapa kendala yang muncul selama pelatihan kultivasi spirulina ini ditunjukkan ada peserta yang masih kurang memahami bagaimana menentukan apakah yang dilakukan itu berhasil ataukah tidak karena yang diperoleh dari hasil kultivasi spirulina ini sedikit atau mungkin kesalahan dalam pemilihan metode yang tepat dalam melakukan kultivasi spirulina. Sehingga kedepan perlu diadakan lagi pelatihan dan pendampingan yang lebih intensif lagi tentang cara kultivasi spirulina yang benar agar mendapatkan produk yang maksimal

\section{DAMPAK DAN MANFAAT KEGIATAN}

Hasil pelatihan tentang kultivasi spirulina ini, diharapkan peserta pelatihan dapat menyebarluaskan pengetahuan dan memotivasi kepada para peserta lainnya untuk memanfatkan potensi spirulina menjadi suatu bentuk produk usaha baru yang nantinya dapat menghasilkan pendapatan dan meningkatkan kesejahteraan perekonomian dikemudian hari.

\section{KESIMPULAN}

Secara keseluruhan kegiatan pelatihan kultivasi spirulina berlangsung lancar dan sukses, sesuai dengan jadwal yang telah ditentukan oleh tim PKM. Semua tahapan pelatihan, mulai dari penyampaian materi, diskusi dan dilanjutkan dengan praktik, dapat diselesaikan dengan baik oleh peserta pelatihan. Secara umum peserta menyatakan antusias dan senang karena selama ini belum mengetahui tentang teknologi mikroalga yang dapat memberi manfaat untuk menghasilkan beragam bahan kimia dan senyawa aktif biologis, seperti vitamin, 
pigmen karotenoid, protein tinggi sekitar 60$70 \%$, lipid dan polisakarida, kecernaan tinggi, dan kandungan seimbang antara beberapa asam amino esensial. Para peserta pelatihan mengaku dan merasa kebutuhannya telah terpenuhi dalam mendapatkan ilmu serta keahlian baru tentang kultivasi spirulina dan peserta pelatihan berharap akan ada lagi pelatihan lanjutan untuk meningkatkan ketrampilannya.

\section{UCAPAN TERIMAKASIH}

Pelaksanaan pelatihan untuk menyebarluaskan PKM tidak terlepas dari peran kerjasama berbagai pihak, antara lain Pimpinan Universitas PGRI Adi Buana Surabaya serta Mitra dalam hal ini SMA/SMK di Surabaya dan Sidoarjo yang telah memberikan kesempatan kepada siswanya untuk mengikuti kegiatan PKM ini.

\section{REFERENSI}

Agustina, S. dan S. Herman. 2016. Potensi Mikroalga sebagai Bahan Kimia. Portal: Media Ilmiah Bidang Kimia dan Kemasan. Vol 1(3): 122-130.

Baweja, P., S. Kumar, D. Sahoo, and I. Levine. 2016. Seaweed in Health and Disease Prevention. Chapter 3: Biology of Seaweed. Edited by J. Fleurence and I. Levine. Elsevier: 41106.

Couteau, C. and L. Coiffard. 2016. Seaweed in Health and Disease Prevention. Chapter 14: Seaweed Application in Cosmetic. Edited by J. Fleurence and I. Levine. Elsevier: 423-441.

Neto, D.C., F.B. de Camargo, and P.B.G.M. Campos. 2014. Cosmetic composition containing Spirulina and cosmetic treatment method. Patent US 2014/0023676 A1

Oktarina, E. 2017. Alga: Potensinya pada Kosmetik dan Biomekanismenya. Majalah Teknologi Agro Industri (Tegi).Volume 9 No. 2.

Ugwu, C.U., H. Aoyagi and H. Uchiyama, 2008. Photobioreactors for mass cultivation of algae. Bioresour. Technol., 99: 4021-4028.

Janssen M, Tramper J, Mur LR, Wijffels RH. 2003. Enclosed outdoor photobioreactors: light regime, photosynthetic efficiency, scaleup, and future prospects. Biotechnol Bioeng;81(2):193-210 
